\title{
Promoting the Reform and Innovation of Ideological and Political Theory around the "Morality and Humanity Education" Core Task
}

\author{
Yafan $\mathrm{Hu}$ \\ Qiqihar Medical University \\ Qiqihar, China 161006
}

\begin{abstract}
Strengthening and improving the teaching reform and construction of ideological and political theory course is an important measure to implement the spirit of the ideological and political work conference in colleges and universities across the country. We should attach great importance to and enhance the sense of responsibility and fully understand the importance and urgency of education and teaching reform of ideological and political theory course; we should implement the spirit of superior documents, combined with the actual situation of the college, strengthen the investigation and study, seize the set hours, curriculum content, practical teaching, evaluation methods and other key issues, advance the teaching reform and construction of ideological and political theory course, give full play to its role of the main position and channel in the implementation of the morality and humanity education" core task, enhance the sense of receipt, and strive to build the ideological and political theory course into an excellent course that student like, life-long benefit, unforgettable.
\end{abstract}

Keywords-ideological and political theory course; morality and humanity education; reform; construction

\section{INTRODUCTION}

The education and teaching work of the ideological and political theory course in colleges and universities is an important part of the main ideological work of the party and the country. It is the main channel and position for the university students to carry out Marxist theory education and ideological and political education so as to establish a correct world outlook, outlook on life and values. The education and teaching work of the ideological and political theory course in colleges and universities is an important part of the main ideological work of the party and the country. It is the main channel and position for the university students to carry out Marxist theory education and ideological and political education so as to establish a correct world outlook, outlook on life and values. Contemporary college students are active in thinking, are in the ideal and faith forming period, their recognition degree of mainstream ideology will directly affect their ability to become a socialist with Chinese characteristics qualified and reliable successor, and even affect the overall quality of our citizens. It requires colleges and universities in the ideological and political theory of education and teaching must strengthen the building, around the morality and humanity education core task, strict implementation of ideological and political theory course construction standards.

\section{THE MAIN ACHIEVEMENTS AND CHARACTERISTICS}

In accordance with the Ministry of Education, "ideological and political theory course construction standards", after three years of continuous efforts, our school ideological and political theory course construction made quite achievements, are:

\section{A. The Establishment of A Unified Leadership of the Party} Committee, Party and Government Co-Management, Coordination of Various Departments of the Leadership System and Working Mechanism

The party committee and the president's office will hold a special meeting regularly to study the construction of the ideological and political theory course. Setting the ideological and political theory into the college "second five" "thirteen five" plan, listing the ideological and moral cultivation as an excellent class as legal basis and the basic principles of Marxist theory, listing the basic principles of Marxism as an excellent college class to build. Marxist college leadership team, all of the party members, all engaged in ideological and political theory teaching, without other part-time. College equipped with office space and teaching equipment, basic library materials, to meet the teaching and office needs.

\section{B. Standardized Teaching Management System, Complete Teaching Archives}

Training program credits, the total time meet the 05 program requirements. Opening a number of elective courses played a role in supporting the ideological and political education. Setting the practice of teaching into the undergraduate 2012 version and the new training program achieve the requirements of 2 credits. Teachers won totally four provincial teaching awards and school-level awards in recent years. 
C. The Establishment of the College of Social Science Fund Project Including Teaching and Research Topics of Ideological and Political Theory Courses

College established the "Qiqihar Medical College Social Science Association", developed a "Qiqihar Medical College Social Science Fund Project Management Measures" to support and protect the ideological and political teachers to declare all kinds of subjects at all levels.

\section{COntinuously DeEPEN THE REForm to ADAPT TO THE NEW SITUATION}

In order to meet the needs of moral education for college students better in the new period, we will continue to study and deepen the reform.

\section{A. Deepen the Teaching Reform}

1) To carry out the specialization of teaching reform:Since 2012, the "ideological and moral cultivation and legal basis" class has achieved the topic of teaching, divided into 1-6 semesters, college pay attention to students to develop education, so that ideological and moral training courses continuous in the school. The 2016 "Outline of Modern Chinese History" class in the teaching system based on the historical time for the order of teaching content reduced to ten topics, set the "professional feelings" oriented humanistic quality education "into the theoretical teaching process, drive the cultivation of students' professional ethics and professional spirit. September 2017 will be the theme of teaching in full swing, "Introduction" "Principles" "situation class" will achieve the topic of teaching. The full release of the thematic lectures will be realized in September 2017, and the "introductory course" and "principle class" and "situation class" will be realized.

2) Revised the 2017 version of the training program: Ensure the ideological and political training program credits, the total time to meet the 05 program requirements. Setting the practice of ideological and political practice into the undergraduate 2017 version of training programs ensure it is not less than 2 credits.

3) Open multiple elective courses: College add "medical and painting art" "medical human body sketch" "art paper cutting" and other courses to assist ideological and political theory teaching in 2017.

4) Active construction of ideological and political practice base: Integrate Qiqihar area of educational resources to build ideological and political theory teaching practice base, and sign a renewal practical agreement with practice base. Develop "thinking and cultivation and legal basis of the practice of assessment files" "Mao Zedong Thought and the theoretical system of socialism with Chinese characteristics", provide assessment file of reference video, the classic selection of books, social survey report guidance topics, through video appreciation, the classic read, social surveys, etc. complete social practice.

5) Expand the frontier technology carrier: Founded the Marxist Institute of WeChat public "social family", outside the classroom college use the network, WeChat, SMS and other technology carriers to interact with students actively, the disseminate Chinese characteristics socialism theoretical educational information, timely understand student needs and problems, passed the new teaching content can not be used in to the students, effectively overcome the limitations of the classroom, expand the student's learning space, to achieve ideological and political theory of teaching practice full coverage.

\section{B. Around the Morality and Humanity Education Core Task, Enhance the Reward Sense of College Students in the Ideological and Political Lessons}

1) Formed "the annual special program work of ideological and political theory teaching quality of Qiqihar Medical College": Purposefully put forward construction goals and safeguard measures to enhance the reward sense of college students in the ideological and political lessons.

2) Carried out a special study of ideological and political education: Carried out questionnaires "Qiqihar Medical School ideological and political theory course investigation" through "questionnaire star", WeChat, paper questionnaires, etc. for students, which more than 2,000 students filling out, that let college master the first-hand information; through the college leaders and students Breakfast, management forum, the secondary school field visits, understand the experience and suggestions of relevant teaching units on the ideological and political .Carry out special lectures, walk into the classroom practically investigate and research, organize the teacher forum, indepth understand the basic situation of ideological and political theory teaching, formed a special research report that pointed out the direction for the next step of construction in our college teaching of ideological and political .

3) Adhere to the main position of Marxism: Introduced the "Implementing the Implementation of the Responsibility System of Ideology in Marxist Academies". strengthen the classroom teaching discipline, adhere to academic research without restricted area, disciplined classroom teaching, implement teaching monitoring, lectures and supervision system, increase the examination and inspection efforts to effectively put an end to any speech violation of the four basic principles in the classroom, contrary to the party and the national line of the guidelines.

4) Focus on experiential teaching: For students generally concerned about the hot, difficult issues, appropriately arranged questions, discussions, debates and other interactive activities, play the role of students to achieve two-way communication. Mainly take the heuristic, reading and reporting, problem researching, interactive, role-playing, classics guiding, case analysis and other teaching methods to mobilize the enthusiasm initiative and creativity of students.

5) Strengthen the inspection efforts on teaching: The Marxism Academy conducts regular instructional examinations, and the college supervisor leads lectured inclass at least 2 sessions per semester. Achieve the leadership 
lectures, supervisors lectures, peer lectures, the course monitoring without missing.

6) Diversified teaching method training: Through the teaching work conference, collective lesson preparation, inter-school observation, area teaching research, academic conference, provincial ideological and political lecture award-winning video observation, etc., enhance consciousness of teachers to take the initiative to improve the teaching method.

\section{Formed Teaching Team, Reasonably Optimize Teacher Team}

1) Strengthen the power of ideological and political teaching: Hired experts and scholars, party and government leading cadres and advanced figures who meet the standards of position to hold a concurrent post of ideological and political theory teachers. Main college party and government leaders take the head to lecture ideological and political theory courses, also including functional departments, cadres, secondary college secretary.

2) Form a thematic teaching team: In the limited teacher resources enhance the teaching strength, strengthen the integration of various courses, break the barriers of teaching research room, optimize and combine the teacher resources, forming the teaching team. Embody the individual responsibility in the teaching, and enhance the responsibility sense of teachers. Organize classroom teaching, improve teaching methods, and strengthen teaching security under the task.

3) Strictly implement the pre-job training system: The new teachers participate in the province, college pre-job training, and take appointment with certificate. Through the demonstration class, observation class, collective lesson preparation, the backbone teacher training, etc., getting on the ideological and political teachers all-round, multi-level Marxism engineering teaching materials training, implementing Marxism engineering teaching materials special training program."

4) Add teacher resources with plan: In 2017, the Marxist Academy was approved for the recruitment program of 3 teachers, and in the first half of the year college has successfully recruited 1 teacher.

\section{Carry out Special Training to Enhance the Level of Teaching and Research}

1) Carry out special training: Invited Dr. Zhang Zhengming, Vice Chairman of Heilongjiang Provincial Social Science Association to the college and made a special report on "writings are for conveying truth, pioneering and innovative ---- how to effectively enhance the ability of philosophy and social science writing".

2) Participate in hospital training: Organize teachers to actively participate in the various types of scientific research, teaching and research work, reports, training organized by college, to enhance the research awareness of teachers.
IV. POLICY SUPPORT, ENSURE THE IDEOLOGICAL AND POLITICAL THEORY COURSE CONSTRUCTION ORDERLY

1) Policy Protection: The main task of the Marxist Academy is to organize and manage ideological and political theory teaching work, as well as teaching, scientific research and so on. Our college will rationalize the scientific and research management system of Marxist theory, combine the scientific and research team construction with ideological and political theory course, and protect it in the policy, cultivating new growth point. Establish the special subject of education and teaching of ideological and political theory course, actively expand the channels of reporting, create conditions to support ideological and political theory teachers in declaring all kinds of topics and participating in various scientific research awards.

2) Strengthen the encouragement: Develop the "financial assistance and incentives method of Marxist academy in teaching and research work", and fund the provincial, city, college teaching, thinking, scientific research projects that obtain the project but not get the parent or college matching funds subject by fund. And reward the provincial and municipal teaching, scientific research projects those have projected and finished.

3) Actively brewing discipline: Through the discipline cultivation, attract the relevant disciplines teaching and research backbone to enrich the team, improving the overall quality of ideological and political theory teachers, enhancing the sense of belonging and accomplishment.

\section{A. Do A Good Job of Teacher Building to Provide A Talent Guarantee for Ideological and Political Theory}

1) Equipped with neat and strong teachers: In accordance with the provisions of the state 1: 350-400 gradually with the proportion of strong ideological and political theory teachers. Encourage and support the ideological and political theory teachers to study on-the-job doctoral degree, to further improve the level of teachers' degree education. Improve the professional and technical posts evaluation criteria, pay attention to assessment of teaching ability and teaching performance, and gradually improve the ideological and political theory teacher title structure. Provide good working conditions, and increase the training efforts on the academic leaders of Marxist theory and the young backbone teachers of ideological and political theory courses, to help them grow as soon as possible.

2) Strengthen teacher social practice: According to the spirit of the CPC and provincial party committee, strengthen the social practice of ideological and political theory teachers, organize themselves and arrange more than one quarter of the ideological and political theoretical courses full-time teachers to carry out a social practice, study tour or academic exchange inside and outside the province, improve teachers' practical teaching ability and comprehensive business quality. 
B. Ensure Work Conditions to Provide Material Security in Strengthening and Improving the Ideological and Political Theory Course

1) Establish a special funding mechanism: College implements the spirit of the relevant documents, on the basis of ensuring the normal administrative expenses fully allocate ideological and political theory teaching special funds according to the standard of 20 yuan per student per year. The special funds is for the ideological and political theory course teaching research, teaching reform, curriculum construction, resource development, academic exchanges, teachers, social practice training and research projects and scientific research awards, high-level academic achievements published subsidies.

2) Broaden the training channels: Strengthen the management efforts of teachers in social practice, training and communication. Broaden the ideological and political teachers to participate in academic exchanges, social practice, training channels, to break the local regional barriers, and from the actual needs select teachers to train and learn.

3) Improve working conditions: According to the needs of the construction of ideological and political theory course, the college has continuously improved the office space and working conditions of the ideological and political theory teaching, and the office of the teachers of the ideological and political theory class has a single room separate by teaching and research office.

\section{Reduce the Scale of Classroom Teaching to Provide the Necessary Conditions in Enhancinge the Effect on Ideological and Political Theory}

Gradually realize the scale of ideological and political classroom alone adjustment, ensure that the scale of the classroom class not more than 100 people.

\section{CONCLUSION}

It is an important task to strengthen the construction of ideological and political theory courses and to improve the teaching quality of ideological and political theory courses. We need to strictly implement the "construction standards", standardize each education and teaching management work, and make a contribution to train qualified medical talents for the socialism modernization with Chinese characteristics.

\section{REFERENCES}

[1] Confidently Put Ideological and Political Work throughout the Whole Process of Education and Teaching [N], Ningning An, China National Newspaper, January 13, 2017, (001)

[2] Earnestly Implement the Spirit of the Ideological and Political Work Conference in Colleges and Universities [N], Wei Chai, China Education Daily, January 7, 2017, (001)

[3] How to Communicate Positive Energy in Ideological and Political Education in Colleges and Universities in the New Media [J], Bin Long, Red Flag Manuscript, 2015, 17th
[4] An Analysis of Xi Jinping 's Educational Thoughts and Ideological and Political Education [J], Guanyong Wu, Journal of Ezhou University, 2017, 3rd

[5] A Summary of the Symposium on Ideological and Political Theory Course in Colleges and Universities in Northeast Area [J], Wen Ma, Journal of Ideological Theoretical Education, 2011,4th

[6] Reflections on the Current Ideological and Political Work in Colleges and Universities [J], Lisi Chen, Journal of China Youth College for Political Sciences, 2017,3rd

[7] “The Four Services” New Ideas of Ideological and Political Work in Colleges and Universities [J], Xiaohui Yang, Zeqiang Zhang. Journal of China Youth College for Political Sciences, 2017,3rd

[8] Research on the Ideological and Political Work in Colleges and Unive rsities Based on the Background of Innovation [J], Xueyang Tao, Mo dern communication, $201619^{\text {th }}$ 